\title{
Miten vastustaa seksuaalista häirintää härskiintyvässä yhteiskunnassa
}

\author{
Hanna Vilkka (2011). Seksuaalinen häirintä. PS-kustannus. 207 sivua.
}

KANNEN KUVASSA mieshahmo on asetellut kätensä naisen takapuolelle - seksuaalisen häirinnän kohteena on useimmiten nainen ja tekijänä mies. STM:n Tasaarvobarometrin (2008) mukaan joka toista 15-34-vuotiasta naista on häiritty seksuaalisesti. Kymmenen viime vuoden aikana on lisääntynyt erityisesti 35-54-vuotiainen naisten häirintä.

Tasa-arvolain mukaan seksuaalisella häirinnällä tarkoitetaan sanallista, sanatonta tai fyysistä, luonteeltaan seksuaalista ei-toivottua käytöstä, jolla tarkoituksellisesti tai tosiasiallisesti loukataan henkilön henkistä tai fyysistä koskemattomuutta erityisesti luomalla uhkaava, vihamielinen, halventava, nöyryyttävä tai ahdistava ilmapiiri.

Sosiologi ja tietokirjailija, VTT Hanna Vilkan kirja selventää seksuaalisen teon, sukupuolisen häirinnän, seksuaalisen häirinnän, seksuaalisen ahdistelun, seksuaalisen kaltoinkohtelun, seksuaalisen hyväksikäytön, seksuaalisen väkivallan, seksuaalirikoksen rajankäyntejä määrittelyillä sekä keskustelee seksuaalisen häirinnän ongelmista lainsäädännössä.

Oman lukunsa saa seksuaalinen häirintä kouluissa ja korkea- kouluissa. Kirjassa käsitellään niin ikään häirinnän ja kiusaamisen lomittumista toisiinsa. Kirjaan on haastateltu eri alojen asiantuntijoita, ja siinä hyödynnetään esimerkiksi sähköpostiviestejä, joita kirjoittaja on saanut opettajilta ja terveydenhuollossa toimivilta.

Kuten seksuaalisuus myös häirintä kietoutuu valtasuhteisiin. Seksuaalinen häirintä (esimerkiksi kähmintä) on osa laajempaa rakenteellista sukupuolten välistä epätasa-arvoa. Häiritsijät ja ahdistelijat ovat valtaosaltaan miehiä, mutta naisten osuus on kasvamaan päin. Osaltaan naisia on suojellut mieskulttuuri, joka ei salli miehen tuoda esiin etenkin naisen aiheuttamia nöyryytyksiä.

Eräässä tutkimuksessa haastatellut pojat ymmärtävät itsekin, että he voivat häiritä juuri siksi, että he ovat tyttöjä fyysisesti vahvempia. Osa nuorista miehistä rakentaa omaa maskuliinisuuttaan kohdistamalla häirintää ja väkivaltaa erityisesti konservatiivisesta normista poikkeaviin naisiin ja miehiin. Vanhempi mies suuntaa seksistiset vitsinsä ja pilailunsa yleensä nuoriin naisiin ja ylemmässä asemassa oleva alempana olevaan. Kiusaamisen, häirinnän ja vallankäytön suhteista työssä ja muualla olisi lukenut enemmänkin, mutta se olisi toisen kokonaisen kirjan aihe.

Yksi luku on omistettu kuvaamaan lainsäädäntöä ja sen vaikutuksia seksuaalisen häirinnän ennaltaehkäisyyn viimeksi kuluneen vuosisadan aikana. Vilkka pohtii myös, miltä seksuaalinen häirintä ja seksuaalirikokset näyttävät tulevaisuudessa. Tasa-arvobarometrin mukaan suomalaiset pitävät seksuaalirikoksista annettuja rangaistuksia liian lievinä.

Kirja on visuaaliselta ilmeeltään tylsän raportin kaltainen. Teksti pitäytyy asiallisen lakonisessa äänensävyssä alusta loppuun. Tärkeintä on asia - ja sitä on. Vilkka käsittelee aihepiiriin kuuluvia ilmiöitä huomattavan monipuolisesti.

Kirja tarjoaa välineitä tunnistaa vaikeasti toisistaan erotettavien ilmiöiden välisiä eroja sekä erilaisia seksuaalisen häirinnän tapoja työyhteisössä, harrastuksissa ja koulussa. Tärkeä osa ovat neuvot, miten toimia joutuessaan seksuaalisen häirinnän kohteeksi tai todistajaksi.

Heikki Silvennoinen 